\title{
Ethnic reasoning in social identity of Hebrews: A social-scientific study
}

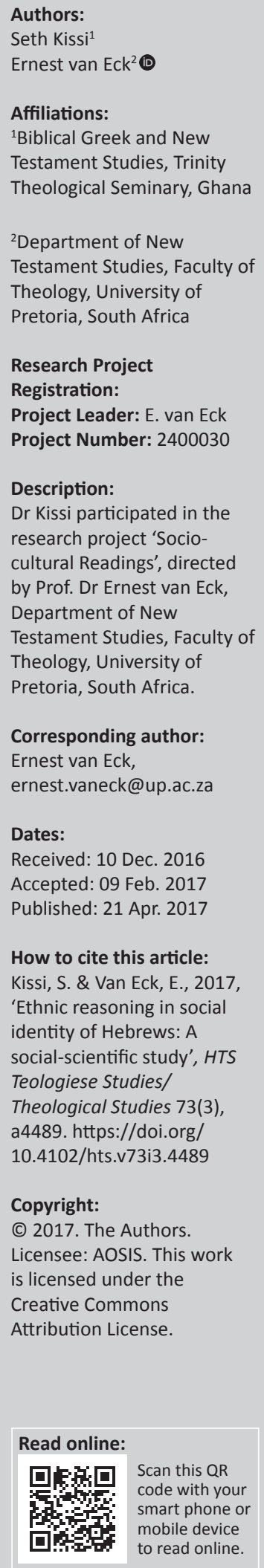

Ethnicity reasoning offers one way of looking at social identity in the letter to the Hebrews. The context of socio-economic abuse and hardships of the audience creates a situation in which ethnicity in social identity becomes an important issue for the author of Hebrews to address. This article is a social-scientific study which explores how the author establishes the ethnic identity of the audience as people of God. While this ethnic identity indicates the more privileged position the readers occupy in relation to the benefits of God accessible to them, it also provides the author with the appropriate social institutions and scripts by which his demand for appropriate response to God and the Christian group becomes appreciable and compelling. The article involves the definition of social-scientific criticism, ethnicity and social identity, and discusses the social context of the letter to the Hebrews. It then explains how some social scripts within specific ethnic institutions give meaning to the demands the author makes from his readers.

\section{Social-scientific criticism}

Social-scientific criticism as an exegetical tool for the interpretation of ancient (biblical) texts is fairly new and still evolving. It makes use of theories and models from social sciences such as sociology, anthropology, archaeology and history, among others. These theories and models offer important information about the sociocultural systems in which the writers and audience of ancient biblical texts lived. Such information throws light on the social interactions in which the issues being addressed in the biblical text took place, giving meaning to the text by providing us with the social expectations within those systems as they find expression in the biblical text. In this light, the biblical text, for Elliott, encodes information about, and derives its plausibility, meaning and persuasive power from the social and cultural systems in which it was produced. ${ }^{1}$ Social-scientific criticism therefore requires examination of the salient and interrelated properties of the society and culture that produced a text under investigation, that is, the institutions and cultural codes that governed ancient thought, institutionalised behaviour and conventional modes of interaction for the interpretation of biblical texts (Elliott 2001:10). Such examination is premised on the realisation that any text is the product of a specific social system, and that one has to understand the social system behind the text before the text can be understood.

\section{The socio-cultural context of Hebrews}

In spite of the uncertainties about the authorship and audience of Hebrews that make Hebrews appear enigmatic, some important information about its social context is not difficult to deduce from the text. The initial assumption that Hebrews was written mainly to Jewish Christians is now giving way in some current scholarship to the view that the audience was made up of both Jewish and non-Jewish believers. ${ }^{2}$ Among other things, the topics for elementary instruction in Hebrews 6:1-2 would be familiar to Jews but not to Gentiles. Hence, it is a Gentile audience that would find it necessary to learn them. The subject of repentance from dead works in Hebrews 6:1, for instance, suggests recipients who had converted from paganism and therefore would likely have been Gentiles. In addition, the mention of Timothy and his inclusion in the author's travel plans (Heb 13:23) suggests that the particular congregation was formed as a part of the Pauline mission which had as its goal the raising up of Gentile Christians (see DeSilva 2012:35). It is, however, important to note that none of the arguments in favour of Gentile or Jewish audience removes the possibility of 1.Chalcraft (1979:12-19) and Elliott (2001:10-12) offer detailed description and definition of social-scientific criticism. 2.DeSilva (2012), Ellingworth (1993), Ekem (2008) and Schenk (2003) are among scholars who represent the view of a mixed ethnic audience.

Note: This article represents a reworked version of aspects from the PhD dissertation of Seth Kissi, titled 'Social identity in Hebrews and the Akan community of Ghana', in the Department of New Testament Studies, University of Pretoria, with Prof. Dr Ernest van Eck as supervisor. 
mixed audience (Puskas 2016:n.p). While scholars such as Ellingworth (1993:80), Hawthorne (1979:1501) and Schenck (2003:103) hold that Hebrews addresses a situation in which there was pressure on the recipients to relapse into Judaism, DeSilva (2012) and Muir (2014) have argued that the pull on the audience came not only from Judaism but also from other dominant social groups such as the family, trade associations and the city from which the readers had come to join the Christian group. It is reasonable therefore to hold a mixed audience of Jews and Gentiles for Hebrews as a purely Jewish or Gentile congregation would be difficult to assume in the prevailing circumstances of the time. ${ }^{3}$

The acceptance by the believers of the Christian faith made the believers appear as deviants in the eyes of members of their former associations, who cherished the values of the Hellenistic culture and the Jewish religion. Members of their former associations would put some pressure on them in order for the recipients to abandon their new faith and return to their former dominant groups. This pressure included social hardships as the believers were publicly exposed to taunts and affliction (Heb 10:33), and economic hardships in the confiscation of their possessions (Heb 10:34). Some of them may have been put in prison for which reason they were exhorted to remember those in prison and those mistreated (Heb 13:3). In the past, the believers had become companions of those mistreated and sympathised with the prisoners (Heb 10:33-34). This involved the risk of death, as noted by DeSilva (2012:47, citing Wansink 1996:80). The pressure mounted on the believers had been sustained for such a long time that the believers were beginning to feel its impact. Now, some of them had stopped attending the Christian meetings, apparently concealing their Christian identity so as to escape the social hostility against them (Heb 10:25). The author rightly discerned the disastrous consequences of such moves on the part of members of the Christian group. ${ }^{4}$ This prompted his urgent address of the situation. The author's description of the tendencies that resulted in such withdrawal from the Christian group as 'roots of bitterness' and the withdrawal itself as 'crucifying Christ and holding him up to contempt', coupled with the pronouncement of extreme forms of judgement for such offenders (Heb 12:15, 6:6, 10:27), are indicative of the seriousness of both the situation and the author's attitude towards it. Among the many strategies the author finds for addressing the situation is ethnic reasoning which the author employs with relevance for the readers' social identity.

\section{Theories on social identity and ethnicity}

The most widespread definition of social identity is the one offered by Henri Tajfel (Clarke \& Tucker 2014:43), who is identified as the founder of social identity theory

3.Ekem notes that in the wake of the extensive and pervasive influence of Hellenism on Jewish and non-Jewish communities of the then Graeco-Roman World, as well as on Jewish and non-Jenish comsitisation of world viaco-Roman Romana, it was illusory to conceive of a 'pure Jewish-Christian' or a 'pure GentileRomana, it was illusory to conceive
Christian' identity (Ekem 2005:97).

4.DeSilva (2012:163) points out that defection from the Christian group would erode the Christian plausibility structure and jeopardise exponentially the commitment of those who remain thereafter.
(Esler 2014:13). He defines social identity as 'that part of the individuals' self-concept which derives from their knowledge of their membership of a social group (or groups) together with the value and emotional significance attached to that membership' (Tajfel 1982:2). In this sense, social identity is the self-image one has of oneself as a result of one's membership in a group. The elaboration of the theory by Turner (1984), a student of Tajfel, in social categorisation leads to the identification of three basic stages of social identity formation: categorisation, identification and comparison (see also Kuecker 2014:69). By categorisation is meant the division of the social world into assessable groups of entities involving depersonalisation in which personal identity is subsumed by the characteristics of the group categories in view (Kuecker 2014:70). This leads to stereotypical ways of regarding members of a group so that there is less emphasis on description of individuals within a group who now bear a common label of the group's image. It is such a perception that leads to descriptions such as 'Cretans are always liars' (see, e.g., Tt 1:12; Kuecker 2014:70). The second stage is identification. One's knowledge and recognition of one's membership of a group leads to the internalisation of that group's image in which one sees oneself and is seen by others. The final stage of comparison is the result of identification and internalisation of the groupimage. One then begins to compare oneself with others on the basis of the self-image one derives from one's group, resulting in either one's positive or negative social image that is to say, if the other person in the comparison is assessed to have a better social image, one's evaluation of one's social identity becomes negative and vice versa.

The term 'ethnicity' was coined by the sociologist W.L. Warner in 1942 and is derived from the Greek है $\theta v o \varsigma$ (ethnos), used originally to describe groups such as men, women or the citizens of a town (Van Eck 2014:52, n.4). Duling shows how the term was used in ancient Jewish literature to refer neutrally to the 'people' in the world, and occasionally for Jews themselves, later increasingly becoming a designation for outsiders, often with negative associations (Duling 2010:69). Ethnicity is a complex concept embracing many aspects of one's social life. Abundant literature shows that ethnicity is a dynamic process influenced by different cultural, social, political and economic factors (see, e.g., Chae 2001;2002:19; Hall 2014:51; Horboken 2004:215; Yntema 2009:146). There are several theories on ethnicity. Mention can be made of primordialism, constructionism, instrumental, social psychology and ethno-symbolism. Referring to what has always existed from the beginning, primordialism regards members of ethnic groups as usually having powerful, deep-seated feelings that they believe are natural, sometimes even sacred, and have been there from the very beginning (Duling 2010:71). Language, family, place (land) of origin, custom and religion are five features that characterise such groups and they are emphasised by the groups themselves (Duling 2010:71). Constructionism, championed by the Norwegian sociologist Fredrik Barth, presents a view of ethnicity that is not natural, inherent and fixed, but 
freely chosen, fluid and changeable - continually constructed in new contexts in relation to outsiders' views (Duling 2010:72). It does not see the five features of ethnicity language, family, place (land) of origin, custom, and religion of primordialism as determinants of ethnic affiliation, but as social organisation of cultural differences. Constructionism has modified forms in instrumentalism, social psychology and ethno-symbolism. While instrumentalism refers to the construction of an ethnic group's identity in an attempt to advance its own socio-political self-interests such as the use of one's ethnic identity to win a scholarship, social psychology is about an ethnic group's development of myths about its collective honour after emerging victorious in a competition with other ethnic groups which are stereotyped in the myth ethnocentrically as dishonourable (Duling 2010:72). A third modification, ethno-symbolism, examines an ethnic group's longing for its past 'golden age', illustrated by its myths of origin and election and its capacity to endure, yet adapt (Duling 2010:72, following Armstrong 1982).

\section{Social identity in ethnic reasoning}

With these theories on ethnicity in view, it is needless to say that there is social identity in ethnic reasoning. Sparks suggests that our comprehension of a given ethnic community is achieved primarily as we come to identify its discursive strategies of self-definition, and also as we understand the devices it uses to distinguish itself from other communities (Sparks 1998:18). Ethnicity, in this sense, provides group identity by which members of one ethnic group evaluate their social identity in comparison with members of other ethnic groups.

While looking at how Hebrews portrays the social identity of the audience in terms of intergroup comparison and competition, this article also focuses on how the author makes use of the social scripts within ethnicity to advance its course of persuading the readers to the desired end. The discussion of ethnic reasoning in Hebrews will make use of the summary of Duling's discussion of cultural features of ethnicity, which includes kinship, myth of common origin, homeland, customs, language, shared historical memory (real or imagined), religion, phenotypical features (observable physical features) and name, with the exception of phenotypical features which are not applicable because the recipients do not constitute a natural ethnic group.

\section{Hebrews' use of ethnic reasoning in social identity}

Hebrews' use of ethnic reasoning is in line with the tradition of many New Testament writers. There is much to say about how Christians used ethnic reasoning to create a collective identity in the early years of Christianity. In defining and redefining themselves as a people in the Graeco-Roman world of the first century, many New Testament writers used concepts of ethnicity to draw out a distinctive identity for believers which while identifying Christians in terms that pertained in dominant, powerful and respected groups like
Jews and Romans still presented the Christians as superior to such groups. Buell intimates that Christians found in the concepts and language of ethnicity of the time an avenue from which they could establish the legitimacy of their claim to how they presented themselves. Christians referred to themselves using language that their contemporaries would have understood as positioning Christians as comparable to groups such as Jews, Greeks, and Romans: the terms ethnos, laos, politeia [Greek], genus and natio [Latin] pepper early Christian texts (Buell 2005:2). It has been observed that Paul formulates an argument for how non-Jews can acquire Abraham as their ancestor through Christ (Buell 2005:46). Buell (2005:48) maintains that religious practices continued to be correlated with race, ethnicity and civic membership throughout the imperial period. There is, therefore, a participatory nature of ethnicity in religious practices whereby by participating in the appropriate religious practices one assumes the ethnic identity of the ethnic group associated with that particular religion.

\section{Establishing ethnic identity of the readers \\ Kinship}

The most important indication of status in the Mediterranean world was family and, except for magical texts, genealogies usually followed a single male line ('unilinear patrilineal descent') with the most common form of identity being ' $X$ son of $\mathrm{Y}$ (son of Z)', as in 'James son of Zebedee' (Mt 4:21; Duling 2010:74, Malina 2001:5). In Hebrews, the author employs ethnic expressions of kinship to describe his audience. The readers are described as 'God's household' (Heb 3:6) and God's 'many sons and daughters' (Heb 2:10, 14, 12:5-10), 'brothers and sisters' to Christ and to one another (Heb 2:11; $3: 1,12 ; 10: 19 ; 13: 22)$. As DeSilva (2012:156) observes, the readers are joined by a common genealogy (as God's 'children' [Heb 2:10] and 'Abraham's descendants' [Heb 2:16]) into a single family. Moreover, the believers and Jesus all share the same source in God, their father (Heb 1:11).

\section{Homeland (city)}

In the Greco-Roman world, a person's native land gave him or her a sense of identity and belonging (DeSilva 2012:72). Living away from one's native land meant the loss of status that a person enjoyed in that native land, particularly the status that came from the honour developed by the family over generations (DeSilva 2012:74). This loss was aggravated by limited access to acquiring honour in the foreign land (DeSilva 2012:74-75). The stranger or foreigner generally

5. We are reminded that the conception of people of God as kin takes a particularly Christ-centred focus (DeSilva 2000a:200). It is now attachment to Jesus that determines whether or not a person is in the family, rather than the person's bloodline or natural lineage (DeSilva 2000a:200). Now since God promised to establish the new covenant with the household of Israel and of Judah (Heb 8:8) the audience who have now become heirs of that covenant are now the household of audience who have now become heirs of that covenant are now the household of Israel and Judah. The promise of rest Israel looked forward to is presented in Hebrews as a promise to Abraham and his co-heirs (Isaac and Jacob; Heb 11:8, 9). But the heavenly city they were looking forward to is still to come' (Heb 13:14), and yet believers already have access to it (Heb 12:22). As Steyn has noted, 'the heavenly rest is both still to be realised and yet accessible' (Steyn 2011:438; following Lincoln 2006:95). The believers in this sense are the true inheritors of what was promised to Israel and the true descendants of the Patriarchs of Israel for that matter. 
lacks citizenship in the new locale, and thus lacks the rights and protection citizenship afforded against insult, abuse and assaults on property or honour (DeSilva 2012:75).

The audience of Hebrews suffered a fate comparable to people who lacked citizenship in the city where they lived. ${ }^{6}$ The public exposure to reproach and affliction the readers endured (Heb 10:33) is typical of the shaming technique employed by the society to coerce people to return to a life that respected the values of the society from which they had turned away (DeSilva 2012:46). The plundering of the readers' property, for instance, was possible so long as they were treated as strangers with no rights to seek state protection (Heb 10:34). This is because those who naturally were citizens of the city where they lived and of the Roman Empire had given up the essential things that marked them as Roman citizens and citizens of the city. That is to say, they no longer participated in the sacrifices to the gods that sought the peace and progress of the empire (and for that matter their city). ${ }^{7}$ Such a practice was now part of 'dead works' from which they had to repent (Heb 6:1; cf. Heb 9:14). As part of their repentance from 'dead works', they had given up the veneration of the emperor, an act which could be seen as a political threat to the empire. The peoples' association with the Christian group therefore sent clear indications of their deviant practices to the non-Christian citizens of the city. ${ }^{8}$ When Abraham, Isaac, Jacob and Sarah were presented as models of faith, what the author held up for emulation was their living as strangers and exiles on earth (Heb 11:8-14). The author found this relevant insofar as the readers lived as strangers too.

Aware of this situation, the author tries to set the minds of his audience on another city for which they should strive so that they could endure their current loss of citizenship. For the author, although the city lies in the future for his audience (Heb 13:14), it still is a present reality for they have actually come to Mount Zion, the city of the Living God and the Heavenly Jerusalem (Heb 12:22). In this sense, they are just like Abraham who sought an abiding city when he lived as a sojourner in tents because he was looking for an abiding city (Heb 11:8-10). ${ }^{9}$

6.This is in terms of how they were treated and not mere citizenship of a city.

7.That is, if the readers were located somewhere other than Jerusalem or any other Jewish city. If they were in a Jewish city, they would be considered as heretics and treated as such. Exclusion from the synagogues was among the social mistreatment treated as such. Exclusion from the synagogues was among the social mistreatment that was their lot (Jn 9:35). Even to be seen talking to a believer in Jesus was to run
the risk of being accused of heresy in post-70 reconstituted Judaism [see Dunn (1990:119)].

8.Kippenberg (1990:119) has noted that for the citizens of Smyrna the term christianos implied a rejection of traditional ancestral religion, and this implication was recognised by those to whom this name was applied as well as by the officials of the Roman Empire. He further explains that the Christians did not remain strangers to the term, for they abandoned the local laws and cults of gods themselves (Kippenberg 1990:119).

9.The point in talking about Abraham, Isaac, Jacob and Sarah (Heb 11:8-11) was to show that they were people who were not concerned about where they came from (natural homeland) or to where they could have returned. Instead, they desired better city prepared for them by God. Hebrews makes this clear: [ $t$ ] hese all died in better city prepared for them by God. Hebrews makes this clear: $[t]$ hese all died in faith without having received the promises, but they saw them from a distance, greeted them, and confessed that they were foreigners and temporary residents on the earth. Now those who say such things make it clear that they are seeking homeland. If they were thinking about where they came from, they would have had an opportunity to return. But they now desire a better place - a heavenly one. Therefore God is not ashamed to be called their God, for He has prepared a city fo them (Heb 11:13-16).

\section{Religion}

Religion in the Mediterranean world was embedded in family and politics so that one could speak of household religion or political religion (Duling 2010:74-76, following Carter 2001:22; Cohen 1999:28; Neils 1992). It was therefore not surprising that elements of ethnicity such as myths of origin, ancestors, homeland and many others reflect in the religion of many people. But because religion is about faith in a god(s), loyalty to the god(s) of a people features prominently in many religions, especially Israelite religion. Moreover, elements such as priests, sacrifices, worship and their related practices are found in most religions of the Mediterranean world. Hebrews presents Christianity as taking its roots in the religion of the people of Israel and provides an important link between the readers and Israelite history in the expression of faith in the God of Israel and continuity with the religion of the same people (Heb 1:1-2). We find in Hebrews the use of strong religious language that identifies the believers as participants in the true religion God promised the people of Israel. The audience is identified as beneficiaries of the new covenant, of the high priest who ministers in the true and heavenly tabernacle, and of the better sacrifices (Heb 7-10:18). The recipients of Hebrews have religious designations as 'holy brothers and companions' in a heavenly calling, who are to consider Jesus, the 'apostle and high priest' of our confession who was faithful to the one who appointed him just as Moses was in all God's household (Heb 3:1-2). Because Christ has performed a better sacrifice than that of the Levitical priests, the believers have no other sacrifice to offer except a sacrifice of praise (Heb 13:11-15). ${ }^{10}$

\section{Myth of common ancestry}

Tracing the origin of an ethnic group to a god or ancestors is a very important factor in ethnic sentiments of people. We are told Herodotus wrote that 'nations' traced their origins to their ancestral gods and heroes (Hall 1997:41-43). Speaking of Israel's ethnicity as socially (re)constructed, Cromhout (2014:537-538) reminds us that in antiquity Israelite identity was about loyalty to God and honouring the traditions and customs of the ancestors; remembering the past was always done to negotiate social realities and construct identities in the present to ensure the ethnic group's survival. This 'god factor' in ethnic sentiment was so important that both Romans and Judeans considered themselves to be God's 'chosen people' (Duling 2010:75, citing Carter 2001:22). We are also reminded of how Greek and Latin historians wrote to reinforce ethnic

10. Even this is in line with Israel's cultic practice because the bodies of those animals whose blood is brought into the most holy place by the high priest as a sin offering are burned outside the camp. The believers should therefore go outside the camp where Jesus was also crucified and share reproach with him, offering a sacrifice of praise there since they have been sanctified by that sacrifice of Christ (Heb 13:1115). The author speaks of a redemption that took place by the blood of Messiah which was more effective than that of animals in the old covenant (Heb 9:12, 13) By the sacrifice involving his blood those who are called might receive the promise of the eternal inheritance (Heb 9:15) because a death has taken place for redemption from the transgressions committed under the first covenant (Heb $9: 15$ b). In these verses, the redemption the believers have through the blood of the Messiah and mediator of the the Messiah and mediator of the new covenant is actually meant to effectively cleanse the people from all the transgressions committed under the first covenant. The recipients of Hebrews are made to have an identity that both resonates and as contiguity with that inheritance and their redemption and cleansing from sin. There is no doubt that the promise of the inheritance and redemption that the believers now have are part of the ethnic heritage of the people of Israel. 
identity (Duling 2010:75). The author of Hebrews traces the origin of the Christian group to the same God who spoke to the ancestors of Israel (Heb 1:1-2), and draws on examples from the ancestors of Israel to exhort his people (Heb 11). All these would produce an identity for his readers in which they share a common God with Israel and, for that matter, share in his promises to his people for a better homeland and rest. The ethnic effect of the writer's argument for the social identity of his readers cannot be overemphasised. ${ }^{11}$

\section{Shared historical memories}

An important feature of ethnicity in the Mediterranean world was shared historical memories. Romans had accounts of the founding of Rome (Plutarch, Rom n.p. in Duling 2010:74-76). Greek and Latin historians wrote to reinforce ethnic identity (Duling 2010:74-76).

The author of Hebrews employs shared historical memory in his exhortation to the audience to strengthen their commitment to the Christian community by engendering the reaffirmation of their communal identity with reawakened passion and emotion which characterised the memory now recalled. ${ }^{12}$

The author narrates more remote history of Israelite heroes whose faith and endurance should be examples for his audience (Heb 11). The writer's aim was to show that by faith (faithfulness or loyalty), these people won God's approval. ${ }^{13}$ To the extent that the writer recalls at various instances aspects of the history of historic Israel, his aim was to draw some continuity with his audience as a foundation for his exhortation. Examples of these can be found in the following: the speaking of God to the fathers through the prophets (Heb 1:1), the rebellion in the wilderness (Heb 3:7-19), Abraham's payment of tithe to Melchizedek and the priesthood of the Levitical order vis-à-vis that of Christ (Heb 7), the promise of a new covenant (Heb 8:7-13) and the regulations for worship in the tabernacle (Heb 9). The author also touches on their immediate historic memory: They are to remember the suffering of Jesus when he was tempted (Heb 2:18; 4:15, 16), because he is one of their own and their brother in sharing with them the same flesh (Heb 2:14). They are also to remember their leaders who spoke God's word to them (Heb 13:7). These leaders now belong to the past (not their current leaders). In remembering them, they are to observe the outcome of the lives of the leaders and imitate them. They should also remember their own past which should urge them to continue in their own past exemplary life (Heb 10:32-35).

11.As Johnson (2006:65) has observed, 'For Hebrews, those who confess Jesus find their ancestors in the story of Israel'. Very important features of the origin of the people of Israel are the redemption from Egypt, the wilderness experience and pilgrimage to the Promised Land. The author of Hebrews recounts this story in Hebrews 3:7-4:11 in a way which among others establishes that the continuity of God's people is of great importance (Cockerill 2012:154).

12.As Johnson has noted, the act of memory is not a simple recall of facts from the past. It is rather making present to mind and heart the experiences that shaped and continue to shape their identity (Johnson 2006:268).

13.The language used by the author to describe these heroes of faith ends up making the heroes the ancestors of his audience as well: 'For our ancestors won God's approval by it' (Heb 11:2). In effect, Israel's ancestors become the ancestors of the Christians as well.

\section{Name and language}

Name and language are ways employed in ethnic reasoning to differentiate between groups in the Mediterranean world of the first century. Duling (2010:74-76, following Hall 1997:47) tells us that Greeks ('Hellenes'), Romans and Judeans identified ethnic groups by their names, especially as related to homeland, and often appositionally. This naming and labelling of people was done usually to show that the group doing the labelling was better or superior. Herodotus, for example, labels Persians, Egyptians, Scythians and Libyans 'barbaroi', and that the Romans considered Greeks and Egyptians as inferior (Duling 2010:76).

The writer of Hebrews does not clearly use such words to indicate superiority of the Christian ethnos or inferiority of the outsiders. Nonetheless, he has descriptions of his audience and references to outsiders that suggest that his audience are better (or superior). For example, his readers are God's house (Heb 3:6) and have come to share in Christ (Heb 3:14). The wilderness generation rebelled, provoked God and sinned, and their bodies fell in the wilderness. God swore they would not enter his rest and they could not enter it because of unbelief - a fate in which the author finds the Jews (Heb 3:16-19). But the believers can draw near to the throne of grace (Heb 4:16). The author feels better things in the case of his audience, things that belong to salvation rather than things that make them comparable to a land that has received all the needed cultivation and yet yielded thorns and thistles (Heb 6:7-9). The readers are not those who embrace worldliness in preference to the community as apostates and reaffirm the values of the world, which permit those outside the community to regard Jesus Christ with contempt as some of them had done and no longer belong to the Christian group (cf. Heb 6:6, Heb 10:25). Rather, they are the enlightened people of God who know what is right from wrong (Heb 6:4-5) as opposed to those outside the group considered to be in the dark (cf. Heb 10:32). ${ }^{14}$ They have also tasted the heavenly gift, emphasising their present experience of the reality of the heavenly blessing. They share in the Holy Spirit, implying that their experiences are not of the material but spiritual. They have also tasted the goodness of the word of God and the powers of the age to come, an expression that situates their experience in the blessings of the expected eschatological kingdom which they apparently experienced in the miracles and signs that characterised the preaching of the gospel. All these are the better things felt about the believers of which the author is sure - things that belong to salvation (Heb 6:9). They have further demonstrated good works for which God will reward them; therefore they should continue to show the same earnestness (Heb 6:10-11). They will receive what has been promised by doing God's will in their endurance (Heb 10:35). They are not of those who shrink back and are destroyed, but those who have faith and preserve their souls (Heb 10:39). They are surrounded by so

14.The believers, until they joined the Christian group, were themselves not..... enlightened and were in the dark as those outside the Christian group are considered. This is the impression one gets from Hebrews 10:32: 'But recall the considered. This is the impression one gets from Hebrews 10:32: 'But recall the
former days when, after you were enlightened, you endured a hard struggle with sufferings'. 
great a cloud of witnesses who bear testimony to the possibility of successfully running the race. These witnesses also cheer the readers on as they run their own race (Heb 12:1). They are God's legitimate children and suffering is God's discipline, the way he trains his children whom he loves (Heb 12:8). Suffering as discipline is not incidental but expected, because it is the race set before them (Heb 12:1).

By using the foregoing features of ethnicity, of which the author has no doubt, the author in effect is establishing for his audience an ethnic identity as the people of God. The readers are the new Israel in a new covenantal relationship with God as the covenant with historic Israel becomes obsolete (Heb 8:13). Such ethnic identity should be understood as reaffirmation and enforcement of the self-understanding of the readers. Within their current circumstances, the author finds it necessary to reawaken such ethnic identity in an environment where they were living as strangers even for those who naturally belonged to the city in which they lived. They were now strangers and deviants on account of their joining the Christian minority group. With this reawakening of ethnic identity, the readers should be able to stand boldly, presenting themselves as such and be recognised as such. One should expect this insofar as all the ethnic features used by the author are understood as the way by which a group of people wishes to be identified as unique and distinct from other ethnic groups as held in the ethnic theory of constructionism.

\section{Implications of their ethnic identity for their response to god and social identity}

The author uses ethnic expressions that set the minds of his readers on the social institutions that make his call on the readers to respond appropriately to God compelling. The effect of these ethnic descriptions is twofold. Firstly, they serve to indicate that the readers are better placed, that is, they have a better social identity than others in their outgroups. Secondly, they are used in appeals to the readers in their related social scripts that bring out the vividness and urgency of their expected behaviour.

\section{Obligation to return favour within the family}

Receiving something from somebody in the ancient Mediterranean world obliged the receiver to respond accordingly and fittingly towards the giver (Van der Watt 2000:167-168). The gifts of life, as well as the care taken by parents in rearing the child, were normally taken seriously (Van der Watt 2000:167). Because parents cared for their children and gave them what they needed - especially giving them birth - children were obliged to return these gestures by being responsive and obedient, thus honouring their parents (Van der Watt 2000:167). In denying or ignoring this obligation, the child indeed acted against his or her social nature and was consequently viewed in a negative way (Van der Watt 2000:167-168). Parents were often regarded as God's agents who should care for the child (Van der Watt 2000:167-
168). The reason for obeying and honouring the father was consequently not just a command, but could also be religiously explained. By showing honour to their parents, honour was paid to God and vice versa. (Van der Watt 2000:167-168). In calling on the believers to honour and obey God as their father, their social identity as true children of God in a world of competing claims to 'sons of god' is reinforced. It is precisely because they are true children of God that they must honour and obey him.

Throughout Hebrews, everything Jesus did in his humiliation and exaltation was done for the benefit of the readers as the children of God - Jesus' brothers and sisters. Jesus came to destroy the one who has the power of death, that is, the devil, and to deliver all those who through fear of death were subject to lifelong slavery (Heb 2:14-15). Jesus brings many sons to glory (Heb 2:10) and makes propitiation for the sins of his people (Heb 2:17). He suffered when he was tempted so that he is able to help those who are being tempted (Heb 2:18). The believers are now people who share in Christ (Heb 3:14). They are those who enter God's rest because they believe in Christ (Heb 4:3). They can draw near with confidence to the throne of grace to receive mercy and grace because they have a high priest who is able to sympathise with their weakness (Heb 4:15-16). They have been enlightened, tasted the heavenly gift, shared in the Holy Spirit, tasted the goodness of the word of God and the powers of the age to come (Heb 6:4-5). Their hope in Christ gives them better possessions, abiding ones (Heb 10:34). Even the suffering they are going through is God's discipline that is meant for their good (Heb 12:7-11). Theirs is the heavenly city (Heb 12:22), and the kingdom that cannot be shaken (Heb 12:28). All these benefits are available to the readers because God through Jesus, their brother, made them possible.

The author's emphasis on these acts of God's goodness to his people enables the author draw attention to the appropriateness of the response of gratitude and faithfulness to God and the Christian group which is the family and household of God. Hebrews 12:28 makes the connection between God's goodness and their appropriate response clear: 'Therefore let us be grateful for receiving a kingdom that cannot be shaken, and thus let us offer to God acceptable worship, with reverence and awe'. It was with this same reverence that Jesus approached God in prayer and enabled him to be heard, and to be able to remain faithful to God (Heb 5:7). The readers should also have the same reverence for God for all his goodness and hold fast the confession of their hope without wavering as they keep attending the meeting of the Christian group (Heb 10:23-25). ${ }^{15}$ This is the

15.Attridge (1989:90) explains that the speaker's undertaking that he will trust in God (Heb 2:13) is not simply, if at all, a reference to the frailty of Christ in his human condition, nor a simple mirroring of the situation of Isaiah. He argues that the citation is rather an allusion to that which above all is or ought to be the characteristic of all God's children, their faithful reliance upon God (Attridge 1989:90). The citation thus alludes to the theme of faith or fidelity that will become increasingly important as the text develops (Attridge 1989:90). This loyalty is very crucial because everything they stand to benefit from depends on it. As Attridge crucial because everything they stand to benefit from depends on it. As Attridge 1989:90) points out, Christ's brothers and sisters, as derived from the use of Isaiah $8: 18$, suggests a specification of the 'sons and daughters' who are God's children not simply in virtue of their humanity, but above all because they have been 'given" Christ in that community of faith. There is therefore an inseparable connectio between belonging to Christ and remaining in the assembly of his people - one implying the other - and this amounts to a single precondition for the salvation and glory to which the believers are brought. 
appropriate way to return the favour of all the benefits they have received from God their father.

\section{Appeal to shared family qualities}

If what was characteristic of parentage was that parents hand down outstanding qualities to their offspring - such as honour, strength, reliability, and beauty (Malina 1996:49) then the qualities of Jesus portrayed in Hebrews are intended to be typical not only of God, but also of other members of the family of God (the audience in this particular case). Throughout Hebrews, these qualities of Jesus define what must be the right attitude to suffering as faithful members of God's family. Jesus suffered death, tasting death for everyone as a result of which he was crowned with glory and honour, displaying the attitude of suffering in order to gain later (Heb 2:9, cf. Heb 12:2-3). He is faithful over God's house as a son (Heb 3:6). He was tempted, but no sin was found in him (Heb 4:15). Jesus succeeded in his faithfulness because he took to a number of ways: In the days of his flesh he offered up prayers and supplications with loud cries and tears to him who was able to save him from death, and he was heard because of his reverence (Heb 5:7). He learnt obedience through what he suffered and being made perfect, he became the source of salvation to all who obey him (Heb 5:8). For the joy set before him Jesus endured the cross scorning its shame and is now seated at the right hand of the throne of God (Heb 12:2). By all these Jesus managed to endure such hostility against himself from sinners so that as the believers consider him they will not grow weary or fainthearted (Heb 12:3).

The implication for the believers is clear: They too, like Jesus, must not be afraid to taste death as Jesus did and was crowned with glory in the end (Heb 2:9). They should also be found faithful in the household of God (Heb 3:6) so that as they are tempted, no sin (in terms of breaking faith with God) would be found in them (Heb 4:15). To be able to do this, they, like Jesus, should come to him who is able to save them from death and be heard for their reverence (i.e. their respect for God which makes it impossible to break loyalty with him no matter what the situation; Heb 5:7). They can also learn obedience from what they are suffering so that they can be made perfect (Heb 5:8). Like Jesus, they too for the joy of entering God's rest set before them should endure the cross and scorn its shame (Heb 4:3 cf. Heb 12:2). These are the ways by which they are expected to consider Jesus who endured such hostility against him from sinners so that they will not grow weary or fainthearted (Heb 12:3). These are the sure ways of exhibiting the same faithfulness characteristic of God as exemplified in Jesus, his son and brother of the audience. Living with the attitude and conduct of God himself exemplified in the son on account of being his brothers and sisters should serve to enhance one's identity as members of the family of God.

\section{Ethnic significance of Hebrews' religious descriptions of the audience}

The significance of the religious terms in which the audience is described is to be found in ancient Mediterranean society where religion was embedded in family and politics. To talk about one's religion is to talk about one's family. Jesus is presented as the apostle and high priest of the confession of his people (Heb 3:1; cf. Heb 9:11). The audience have a great high priest who has passed through the heavens (Heb 4:14). $\mathrm{He}$ is the source of eternal life to those who obey him (Heb 5:9). Their consciences are purified through the blood of Christ who through the eternal Spirit offered himself without blemish to God (Heb 9:24). He enters the holy places not made with hands to appear before God on behalf of his people (Heb 9:24). He has perfected them as those who are being sanctified by a single offering (Heb 10:14). Their hearts are sprinkled clean from an evil conscience and their bodies washed with pure water (Heb 10:22). They have been sanctified once for all through the offering of the body of Jesus Christ (Heb 10:10). He is the founder and perfecter of their faith (Heb 12:2). These religious descriptions set the audience apart as a people consecrated to God, their father. From Cromhout's analysis, it is evident that Israelite ethnicity conformed to the role and functions of ethnicity in the life of a people and reflected the broader culture of the region in which Israel is located. As such it tended to be more fixed than fluid, insisting on the ways of life of their ancestors in religious practices not merely in order for the people to be religious, but essentially as honourable members preserving the sanctity of their ethnic group. A departure from the religious practices of their ancestors was then seen as a betrayal of their identity as ethnic Israelites (Cromhout 2014:530-543). The intensive religious language used by the author enables him to establish continuity with the religion of the people of Israel so that their continuation in the Christian group does not amount to abandonment of their ancestral religion (in the case of Jewish Christians). Rather, it should indicate their preservation of their ethnic group as the elect people of God in Christ (Jewish and Gentile alike). This is even more so when Christianity is presented as the new covenant God promised their ancestors (Heb 8:8, 13; Heb 9:15, 24). Their being faithful to the faith in Christ, and the Christian group, is therefore being a true people of God who respect and hold fast to the promise of their God to their ancestors. To recognise oneself as the elect and faithful people of God, and to present oneself as such, has value for one's social identity. Such an identity should evoke more faithfulness and commitment to being God's people in the Christian group.

\section{Use of name and language to reinforce desired responses}

Sounding positive about the audience in the author's use of name and language, as noted above, is meant to impress on the readers their better social identity than the impression they have of themselves from their treatment at the hands of society. In the use of such names and language, the author should be heard 
saying to his readers that they are not worse than those in their out-groups. If he is urging them to remain faithful in their suffering, it is because they are privileged both in what they have access to currently in Jesus and what lies ahead of them.

The language used to describe Jesus and his achievements, and consequently the Christian group, speaks to the ascribed honour of the believers. Ascribed honour is about the honour members of a group enjoy from the honour associated with their group. This honour is usually the result of the achievement of one member of the group. The positive selfimage and pride members derive from such ascribed honour provide an important frame in which people of the Mediterranean society can appreciate Hebrews' description of the achievement of Christ and his honour. It also helps to appreciate the import of Christ's achievements, and honour for the audience as people who have lost a positive social image among members of the larger society. Jesus' superiority as the son (of God), as well as the superior benefits that come to them as presented in Hebrews, should be to the effect that the readers are better placed in their privileged position than all others - Jews or Greeks. They are the beneficiaries of the new and better things that have come in the new covenant promised by God to the ancestors of the Jews (9:11). Jesus as son of God should also be set against the 'sons of god' that the emperors were considered to be. ${ }^{16}$ This should make Jesus unique, especially in the roles associated with him in Hebrews 1:2-3 (cf. Heb 2:8). The final word of God has come to them through God's final agent, their brother (Heb 1:2). This is a claim to superior knowledge and priestly mediation in a society of competing knowledge and priestly mediation. ${ }^{17}$ All the qal wahomer arguments of Hebrews, in which obedience and disobedience to the son yield better reward and more severe punishment respectively than those experienced by historic people of Israel, are as a result of this better position the readers occupy in status and privilege. It is therefore imperative that the believers pay closer attention to the message delivered by the son (cf. Heb 2:1-4; Heb 12:25).

\section{Recall of shared historical memory}

While recall of shared historical memory enables the author to strengthen his readers' identity, and reawaken heroic deeds of past generations (and of their own) in the audience, it also enables the author to show that the audience stand in line with the historical experience of the heroes of faith as in a relay race. This is because, on the one hand, the heroes have run the race

\footnotetext{
16.The identification of Jesus as the son of God would ring loud bells in the ears of the readers who knew the emperors as the sons of god. The same can be said about the address of the son as 'God' by God himself. It is observed that the Roman rulers were partly worshipped as gods (Steyn 2004:1101), and that Philo referred to the Logos, one of the divine powers, as God (Steyn 2004:1101). It is possible for the readers of Hebrews to juxtapose all that have been said about Jesus as the son of God and as 'God' with that of the emperors to whom these titles had been applied. This would make them feel the better evaluation of their Christian in-group as well as the positive evaluation of their social identity.

17.Lang (2008:115-116), following Cicero (Dom. 1, 2), observes that in the Roman Republic there were two major types of priests: the pontifices and augeres. The pontifices were referred to as interpretes religionum [interpreters of the divine will] who focussed their activities on burial practices and regulations. They would also mediate the needs of the people to the deities by offering advice to the Senate'. The augeres are interpreters and messengers.' Unlike the pontifices, thes priests do not appear to have mediated the needs of the people to the ruling senate; rather, the augeres were perceived to have access to the deities themselves.
}

of faith before and, on the other hand, their perfection depends on what God is doing now in Christ in which the readers have their current experience (Heb 11:40). The inspiration and lessons the believers should learn from their history include the avoidance of the immoral character of Esau who made a hasty decision for the pleasure of the moment and lost his more valuable and enduring right to inheritance which he later sought in vain to regain. The believers under the pressure of the moment stand in a similar situation as Esau, and should guard against any decision to go for the ease of the moment and miss the eternal reward God has for them. Jesus becomes the sole model on whom the gaze of the audience should be constantly fixed. This makes Jesus the prototypical member of the group, holding the ideal image of the group's character. In his character is embodied the ideals of the group; hence, being like him is being a true member of the group. As they look away to him, they should be able to run the race the way Jesus did, despising the shame and enduring their suffering in faithfulness to God (Heb 12:2). As they recall their own past historical memory in Hebrews 10:32-36, the readers should relive their own experience in which they practiced what they are being urged to do by fixing their gaze on their model, Jesus. Acting as enlightened people, the believers had endured struggle with sufferings, sometimes publicly exposed to taunts and afflictions, and at other times being companions of those who were treated that way. They sympathised with the prisoners and accepted the confiscation of their possessions, knowing that they have better and enduring possession. It is therefore not only in the remote historical memory of the readers that they have reason to remain faithful and endure but also in their immediate past experience. In using shared historical memory this way, the social identity of the audience as true people of God (true Israelites) is reinforced as they are made to see themselves in continuity with the historic people of Israel, especially with faithful Israelites.

\section{Concluding remarks}

This article has indicated that the author of Hebrews speaks to his audience in ethnic terms which has ethnic significance for their social identity and implications for the desired responses intended by the author. The description of the achievement of Jesus and the honour associated with his designation as son of God, as the one who achieves purification from sin by his once-for-all sacrifice, and as the successful and final mediator of God's word has relevance for the readers' social identity in a world of competing priestly mediation and knowledge. The ethnic expressions of kinship by which the author describes the believers have important social expectations familiar to the Mediterranean society. Firstly, in calling believers the household of God, the author is able to demand from the audience the conduct and behaviour characteristic of God who is their father. It also enables him to require that, as children, the readers are obliged to return the favour they have received from God as their father, and stresses how evil it is for them to refuse to return such favour. With the recall of shared historical memory, the author attempts to set the minds of the audience on good examples of the people of God that they should 
emulate and the ones they must avoid, reawakening the spirit of heroism of past generations (in line with whom they stand) in order for them to stand boldly for the faith even in their suffering. The author uses religious descriptions that emphasise the privileged position of the readers, making compelling their appropriate response to God. Making sense of this is not too difficult in the Mediterranean society in which religion is embedded in the family and used for the well-being of the members.

One can therefore conclude that the author of Hebrews found the social institutions related to ethnicity as pertained in the Mediterranean world and the related social scripts as important means by which he applied the lessons of his theological discussions to his audience for the desired responses. He therefore makes important statements with strong relevance for both the social identity of his audience and for the desired attitude to God and the Christian group. This is so because the situation addressed by the author has socio-cultural dimensions in the treatment of the believers by members of their out-groups and the author's own concern for the believers to remain faithful to the Christian group.

\section{Acknowledgements Competing interests}

The authors declare that they have no financial or personal relationships which may have inappropriately influenced them in writing this article.

\section{Authors' contributions}

This article represents a reworked version of aspects from the $\mathrm{PhD}$ dissertation of S.K., titled 'Social identity in Hebrews and the Akan community of Ghana', in the Department of New Testament Studies, University of Pretoria, with E.v.E. as supervisor.

\section{References}

Attridge, H.W., 1989, The epistle to the Hebrews: A commentary on the epistle to the Hebrews, Fortress Press, Minneapolis, MN.

Buell, D.K., 2005, Why this new race: Ethnic reasoning in early Christianity, iBook reader format, Columbia University Press, New York.

Chae, M.H., 2001/2002, 'Gender and ethnicity in identity formation', The New Jersey Journal of Professional Counselling 56, 17-23.

Chalcraft, D.J., 1979, 'Introduction', in D.J. Chalcraft (ed.), The biblical seminar: Socialscientific Old Testament criticism, pp. 13-19, Sheffield Academic Press Ltd, England.

Clarke, A.D. \& Tucker, J.B., 2014, 'Social history and social theory in the study of social identity', in J.B. Tucker \& C.A. Baker (eds.), T\&T Clark handbook to social identity in the New Testament, pp. 41-58, Bloomsbury T\&T Clark, London.

Cockerill, G.L., 2012, The New International Commentary on the New Testament: The epistle to the Hebrews, William B. Eerdmans Publishing Company, Grand Rapids, MI.

Cromhout, M., 2014, 'Israelite ethnic identity responding to the Roman imperium in revelation', in J.B. Tucker \& C.A. Baker (eds.), T\&T Clark handbook to social identity in the New Testament, pp. 59-78, Bloomsbury T\&T Clark, London.

DeSilva, D.A., 2000a, Honor, patronage, kinship \& purity: Unlocking New Testament culture, viewed 20 October 2015, from https://books.google.com.gh/books?id=4 HOGS3lpOY8C\&printsec $=$ frontcover\&dq=desilva

DeSilva, D.A., 2012, The Letter to the Hebrews in social-scientific perspective, Cascade Books, Eugene, OR.
Duling, D.C., 2010, 'Ethnicity and Paul's letter to the Romans', in D. Neufeld \& R.E. DeMaris (eds.), Understanding the social world of the New Testament, pp. 68-89, Routledge, London.
Rouris

Dunn, J.D.G., 1990, The parting of the ways: Between Christianity and Judaism and their significance for the character of Christianity, SCM Press, London.

Ekem, J.D.K., 2005, New Testament concepts of atonement in an African pluralistic setting, SonLife Press, Accra.

Ekem, J.D.K., 2008, Priesthood in context: A study of priesthood in some Christian and primal communities of Ghana and its relevance for mother-tongue biblical interpretation, SonLife Press, Accra.

Ellingworth, P., 1993, The New International Greek Testament Commentary: The epistle to the Hebrews, William B. Eerdmans Publishing Company, Grand Rapids, MI.

Elliott, J.H., 2001, 'On wooing crocodiles for fun and profit: Confessions of an intact admirer', in J.J. Pilch (ed.), Social scientific models for interpreting the Bible: Essays by the context group in honour of Bruce Malina, pp. 5-20, Brill, Leiden.

Esler, P.F., 2014, 'An outline of social identity theory', in J.B. Tucker \& C.A. Baker (eds.), T\&T Clark handbook to social identity in the New Testament, pp. 13-39, Bloomsbury T\&T Clark, London.

Hall, J.M., 1997, Ethnic identity in Greek antiquity, Cambridge University Press, Cambridge.

Hall, T.D., 2014, 'Ethnicity and world-systems analysis', in J. Mclnerney (ed.), A companion to ethnicity in the ancient Mediterranean, pp. 50-65, iBook reader format, Wiley, Chichester. http://dx.doi.org/10.1002/9781118834312.ch4

Hawthorne, G.F., 1979, 'Hebrews', in F.F. Bruce (ed.), New international Bible commentary based on the NIV translation, pp. 1500-1532, Zondervan, Grand Rapids, MI.

Horboken, V., 2004, 'Ethnic communications', in G. Taylor \& S. Spencer (eds.), Socia identities: Multidisciplinary approaches, pp. 119-217, iBook reader format, Routledge, London.

Johnson, L.T., 2006, The New Testament Library Commentary, Hebrews: A commentary, Westminster John Knox Press, Louisville, KY.

Kippenberg, H.G., 1990, 'Name and person in ancient Judaism and Christianity', in H.G. Kippenberg, Y.B. Kuiper \& A.F. Sanders (eds.), Concepts of person in religion and thought, viewed 21 February 2016, from https://books.google.com.gh/ books?id=H_AQzpSLRNoC\&pg=PP7\&dq=ancient+mediterranean+person\&sour ce $=$ gbs_selec

Kuecker, A., 2014, 'Ethnicity and social identity', in J.B. Tucker \& C.A. Baker (eds.), T\&T Clark handbook to social identity in the New Testament, pp. 59-78, Bloomsbury T\&T Clark, London.

Lang, P., 2008, Jesus as mediator: Politics and polemic in 1 Timothy 2:1-7, viewed 23 November2016, from https://books.google.com.gh/books?id=Cbezk7XVnI0C\&pg= PA115\&dq=priestly+mediation+in+the+roman+world\&hl=en\&sa=X\&ved=0ahUKE wjO09rAlr

Malina, B.J., 1996, 'Understanding New Testament persons', in R.L. Rohrbaugh (ed.), The social sciences and New Testament interpretation, pp. 42-61, Hendrickson Publishers Inc., Peabody, MA.

Malina, B.J., 2001, The New Testament world: Insights from cultural anthropology, 3rd edn., viewed 6 June 2016, from https://books.google.com.gh/books?id=Ek3fSY7j RDcC\&printsec=frontcover\&dq=bruce $+j .+$ malina\&hl

Muir, S., 2014, 'Social identity in the epistle to the Hebrews', in J.B. Tucker \& C.A. Baker (eds.), T\&T Clark handbook to social identity in the New Testament, pp. 425-440, Bloomsbury T\&T Clark, London.

Puskas, C.P, 2016, Hebrews, The general epistles, and revelation, viewed 7 February 2017, from https://books.google.com.gh/books?id=KQiMDQAAQBAJ\&pg=PT38\& $\mathrm{dq}=$ gentile+audience+of+Hebrews $\& \mathrm{hl}=$ en $\&$ sa $=X \& v$

Schenk, K., 2003, Understanding the book of Hebrews: The story behind the sermon, Westminster John Knox Press, Louiseville, QC.

Sparks, K.L., 1998, Ethnicity and identity in ancient Israel, iBook reader format, Eisenbrauns, Warsaw, IN.

Steyn, G., 2004, 'Vorlage of Psalm 45:6-7 (44:7-8) in Hebrews 1:8-9', HTS 60(30), 1085-1103. http://dx.doi.org/10.4102/hts.v60i3.601

Steyn, G.J., 2011, 'The eschatology of Hebrews - As understood within a cultic setting' in J.G. van der Watt (ed.), Eschatology of New Testament and some related documents, pp. 429-450, offprint edition.

Tajfel, H., 1982, Social identity and intergroup relations, viewed 26 August 2015, from https://books.google.com.gh/books?id=h_YA9CYXgG0C\&printsec=frontcover\&d $\mathrm{q}=$ social+identity\&hl=en\&

Turner, J.C., 1984, 'Social identification and psychological group formation', in H. Tajfel (ed.), The social dimension - European studies in social psychology, vol. 2, pp. 518-540, Cambridge University Press, London.

Van der Watt, J.G., 2000, Family of the king: Dynamics of metaphor in the gospel according to John, viewed 12 September 2015, from https://books.google.com. $\mathrm{gh} /$ books?id=ZfbpO51yklsC\&pg=PR3\&dq=ancie+mediterranean+

Van Eck, E., 2014, 'Inclusivity as the essential nature of the Gospels', in J. Kok \& J.A. Dunne (eds.), Insiders versus outsiders: Exploring the dynamic relationship between mission and ethos in the New Testament, pp. 49-83, Gorgias Press, NJ.

Yntema, D., 2009, 'Material culture and plural identity in early Roman southern Italy' in T. Derks \& N. Roymans (eds.), Ethnic constructs in Antiquity: The power and traditions, iBook reader format, pp. 145-166, Amsterdam University Press, Amsterdam. 